ISSN 1678-3921

Journal homepage: www.embrapa.br/pab

For manuscript submission and journal contents, access: www.scielo.br/pab

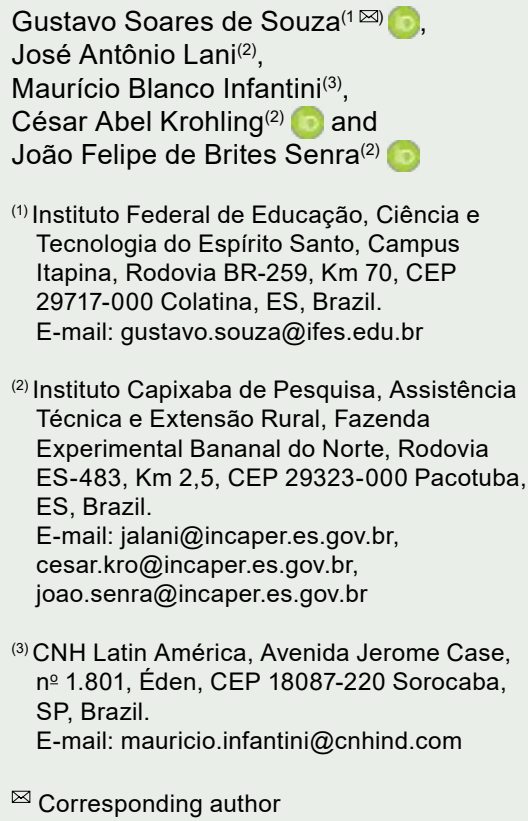

\section{Mechanized harvesting of 'Conilon' coffee clones}

\begin{abstract}
The objective of this work was to evaluate the speed effect of a coffee harvester and its interaction with 'Conilon' coffee (Coffea canephora) clones on the mechanical harvesting efficiency. The experiment was installed in São Mateus, in the state of Espírito Santo, Brazil, in 2012, with 27 clones of early, intermediate, and late fruit ripening. The first harvest was performed after the plant cuttings at $0.5 \mathrm{~m}$ above the ground, in 2016, and the canopy renovation. The plants and the harvester were evaluated in 2018 . The coffee harvester was tested at 0.6 and $0.8 \mathrm{~km} \mathrm{~h}^{-1}$. Measurements were performed for stripping and harvesting efficiencies, fruit loss on the ground, unstripped fruit, defoliation with manual and mechanized harvesting, fruit removal force, and fruit ripening degree. The tests with the coffee harvester indicated a technical feasibility of $88 \%$ average harvesting efficiency, and a $15 \%$ lower defoliation than the manual harvesting. The harvesting speed of $0.8 \mathrm{~km} \mathrm{~h}^{-1}$ results in higher stripping and harvesting efficiencies, in a lower percentage of loss on the ground, and in less unstripped fruit, regardless of the evaluated clones. Fruit removal force and ripening degree influence the stripping and harvesting efficiencies and the percentage of unstripped fruit of 'Conilon' coffee.
\end{abstract}

Index terms: Coffea canephora, agricultural mechanization, fruit removal force, harvester speed, harvesting efficiency.

\section{Colheita mecanizada de clones de café 'Conilon'}

Resumo - O objetivo deste trabalho foi avaliar o efeito da velocidade de uma colheitadeira de café e sua interação com clones de café 'Conilon' (Coffea canephora) sobre a eficiência da colheita mecanizada. O experimento foi instalado em São Mateus, no Espírito Santo, em 2012, com 27 clones com frutos de maturação precoce, intermediária e tardia. A primeira colheita foi feita após o corte das plantas a $0,5 \mathrm{~m}$ acima do solo, em 2016, e a renovação da copa. As plantas e a colheitadeira foram avaliadas em 2018. A colheitadeira foi testada às velocidades de $0,6 \mathrm{e} 0,8 \mathrm{~km} \mathrm{~h}^{-1}$. As mensurações foram feitas quanto à eficiência de derriça e colheita, à perda dos frutos no chão, aos frutos não derriçados, à desfolha com as colheitas manual e mecanizada, à força de desprendimento e ao grau de maturação dos frutos. Os testes com a colheitadeira de café indicaram viabilidade técnica com eficiência de $88 \%$ de colheita média e desfolha $15 \%$ menor do que a da colheita manual. A velocidade de colheita de $0,8 \mathrm{~km} \mathrm{~h}^{-1}$ resulta em maiores eficiências de derriçados e de colheita, em menores perdas no chão e em menos frutos não derriçados, independentemente dos clones avaliados. A força de desprendimento e o grau de maturação influenciam a eficiência de descascamento e de colheita e a percentagem de frutos não descascados de café 'Conilon'.

Termos para indexação: Coffea canephora, agricultura mecanizada, força de desprendimento dos frutos, velocidade da colheitadeira, eficiência de colheita. 


\section{Introduction}

Coffee cultivation is one of the Brazilian agribusiness main activities, occupying an area of 2.13 million hectares in 2019, with a production of 49.31 million bags ( $60 \mathrm{~kg}$ each), and a gross revenue of $\mathrm{R} \$$ 20 billion (Acompanhamento..., 2019). Espírito Santo state occupies less than $0.5 \%$ of the Brazilian territory; however, it stands out as the largest 'Conilon' coffee producer in the country, and the second largest national coffee producer, with 13.5 million bags, out of which 3 million bags are of arabica coffee (Coffea arabica L.), and 10 million bags are of 'Conilon' (C. canephora Pierre ex A. Froehner) (Acompanhamento..., 2019).

The lack of labor and its high cost are the current factors that worry the 'Conilon' coffee producers. In many producing regions, the lack of labor is attributed to the low availability of workers in rural areas and to lower wages than those they may receive in many urban centers (Silva et al., 2013; Souza et al., 2017). Such reduction of the availability of workers in the field has raised the labor cost, especially in the harvesting period, which has led to a higher speculation of harvest prices and to difficulties of crop management, which raised the production costs, making the product less competitive in the domestic and international markets (Lanna \& Reis, 2012; Souza et al., 2017).

The mechanical harvesting has been performed in an efficient and economically feasible way for arabica coffee (Oliveira et al., 2007b; Silva et al., 2013; Santinato et al., 2015b, 2015c; Cunha et al., 2016). The main method uses the vibration of rods in self-propelled or tractor-pulled machines. When vibrating, the rods promote an excitation force on fruit. When this force is greater than the removal force between fruit and plant, the fruit detachment occurs (Crisosto \& Nagao, 1991). Variations of the coffee harvester adjustments alter the harvesting efficiency and are necessary for each condition of the crop (Silva et al., 2013, 2015; Santinato et al., 2015c). These adjustments also influence plant damage and defoliation (Oliveira et al. 2007b; Cassia et al., 2013). The fruit ripening degree and fruit removal force also influence the process of coffee harvesting (Silva et al., 2013, 2015).

The mechanical harvesting of 'Conilon' coffee has been pointed out as a feasible alternative to reduce labor shortage and decrease of the production costs (Souza et al., 2017). However, 'Conilon' and arabica coffee plants differ for their morphological and physiological aspects, as well as for crop management (Verdin Filho et al., 2014; Ronchi \& DaMatta et al., 2017). Thus, studies are necessary to show the feasibility of mechanical harvesters in 'Conilon' coffee cultivations, as well as to identify more promising plant materials; however this information is scarce in the scientific literature.

The hypotheses of this research are: 1, the use of arabica coffee harvester is efficient for the 'Conilon' mechanized harvesting; and 2, the mechanical harvesting process is influenced by machine adjustments and types of clones.

The objective of this work was to evaluate the speed effect of a coffee harvester and its interaction with 'Conilon' coffee clones on the mechanical harvesting efficiency.

\section{Materials and Methods}

The study was carried out in a commercial 'Conilon' coffee crop in the municipality of São Mateus, in the state of Espírito Santo, Brazil (18²43'34"S, 4000'28"W, at $72 \mathrm{~m}$ altitude), with flat relief. The region climate is Aw type, according to Köppen-Geiger's classification (Alvares et al., 2013), with a 1,313 mm mean annual rainfall, and $24.1^{\circ} \mathrm{C}$ mean annual temperature.

The experiment was installed in October 2012, with 27 clones of early (April to May, number 1 to 9), intermediate (June to July, number 10 to 18), and late (July to August, number 19 to 27) fruit ripening. These clones were selected from the active germplasm bank present in the Marilância Experimental Farm, of Instituto Capixaba de Pesquisa, Assistência Técnica e Extensão Rural (Incaper), and received a code (number 1 to 27). Clones with characteristics of interest were collected in private crops since 1985, with plants formed by seed throughout the state of Espírito Santo, and also from the active germplasm bank. The main characteristics considered in the selection for this experiment were tipping (upright plants), plant height (1.8 to $2.8 \mathrm{~m}$ ), leaf area / vigor (medium and high - by visual analysis), mortality rate $(<10 \%)$, productivity $\left(>4,800 \mathrm{~kg} \mathrm{ha}^{-1}\right.$ of benefited grains) and grain size $(>12$ $\mathrm{mm})$.

The coffee trees were planted at of $3.5 \times 0.5 \mathrm{~m}$ spacing and conducted with two orthotropic branches per plant, with 32 plants per plot, being three clones per planting line and 3,456 useful plants. The clones were

Pesq. agropec. bras., Brasília, v.55, e01240, 2020

DOI: 10.1590/S1678-3921.pab2020.v55.01240 
grouped by similarity of the fruit maturation period. Argissolo Amarelo distrófico (Santos et al., 2013) or Ultisols (Soil Taxonomy) was fertilized according to Prezotti et al. (2007). The drip irrigation was managed in order to restore the crop evapotranspiration. Applications of one insecticide, one fungicide, and four herbicides were carried out in 2018. Two prunings were performed in 2017, and plagiotropic branches from less than $0.40 \mathrm{~m}$ above the ground were removed.

Plants and harvester evaluations were carried out in May, June, and July 2018 for early, intermediate, and late maturation clones, respectively, in the first harvest. These plants were cut at $0.5 \mathrm{~m}$ above the ground, in 2016, for the canopy renovation due to a severe drought that reached the region from 2014 to 2016, which prevented evaluations in this period. A coffee harvester of the brand CaseIH model Coffee Express 200 (CaseIH, Piracicaba, SP, Brazil) was used in the tests. This machine features a $55 \mathrm{hp}$, with nominal engine speed of 2,500 $\mathrm{rpm} \mathrm{min}{ }^{-1}$, three-wheel drive, high-flotation tires 500/60-15.5, two vertical agitator rollers with rods arranged in parallel to the horizontal, bulk tank, side discharge system, and dimensions of $3.27 \mathrm{~m}$ of total height and $3.50 \mathrm{~m}$ of operational width. The machine moves over the plants that are in contact in the sides with the rods, which vibrate and strip the fruit through the impact and the vibration transmitted to the plant (Silva et al., 2015; Villibor et al., 2016). This way, fruit go down on the overlapping plates that seal the bottom of the harvester and open and close to permit the entrance and way out of the trunks. Fruit slip on the overlapping plates and go to lateral conveyors in both sides of the trees that move the coffee to screwdrivers. The screwdrivers take coffee to vertical conveyors that move the coffee to an upper horizontal conveyor, and direct fruit to the bulk carrier.

Clone productivity was measured in three plants per plot, in plots with manual or mechanized harvesting, in the same period. The height of harvester rods was adjusted to the region with fruit in the plants. The speed of 0.6 and $0.8 \mathrm{~km} \mathrm{~h}^{-1}$, and a vibration frequency of $16.67 \mathrm{~Hz}(1,000 \mathrm{rpm})$ were used for harvesting. Before mechanical harvesting, two cloths of $2.50 \times 6.00 \mathrm{~m}$ were spread over the soil at three sites (replicates), on two sides of the planting line, under ten plants, to measure fruit losses on the ground and unstripped fruit (Santinato et al., 2015b, 2015c). Fruit measurements were performed by volume (Oliveira et al., 2007a,
$2007 b$ ), using a $20 \mathrm{~L}$ graduated bucket. The mechanical harvesting was performed with a single pass of the coffee harvester. Stripping efficiency was measured by the percentage of fruit harvested and lost on the ground, in relation to plant productivity. Harvesting efficiency, loss on the ground, and unstripped fruit were obtained in percentage, in relation to plant productivity, considering the harvested fruit by the machine, fruit lost on the ground, and fruit remaining on the plant, respectively, after the coffee harvester had passed (Oliveira et al., 2007b; Santinato et al., 2015c).

Defoliation was measured after determining the productivity of clones in three plants per plot, for manual harvesting, and after the coffee harvester had passed in ten plants per plot, using a portable digital scale. Fruit removal force was measured with a portable digital dynamometer (Instrutherm PTR-300, São Paulo, SP Brazil), before the harvester passed, with one fruit being detached at a time. Removal force was measured only on ripe fruit, on two sides of the planting line. The fruit ripening was visually defined by the skin color (exocarp), according to the 'Conilon' coffee fruit development scale (Ronchi \& DaMatta, 2017). A sample of 1.0 L fruit was used in the counting of green, cherries and dried fruit, and used to measure (\%) the fruit ripening degree.

The statistical analysis considered a completely randomized design with thirty-two plants per plot, by applying the analysis of variance (F-test, at $5 \%$ probability) and test of means (Tukey, at 5\% probability), to compare early, intermediate, and late maturation clones and harvest types and speeds. The statistical analysis was performed in the $\mathrm{R}$ software (R Core Team, 2009). Stripping and harvesting efficiencies and percentage of unstripped fruit were related to fruit removal force and ripening degree through the linear regression analysis by the F-test, at $5 \%$ probability.

\section{Results and Discussion}

Stripping efficiency was similar in the tests with the coffee harvester at 0.60 and $0.80 \mathrm{~km} \mathrm{~h}^{-1}$, in the early (91.5-96.0\%) and late (95.9-96.3\%) clones; however, it presented a higher stripping efficiency at $0.80 \mathrm{~km} \mathrm{~h}^{-1}$ in intermediate clones $(93.0 \%)$ and in the mean of the clones $(95.1 \%)$, in comparison to $0.6 \mathrm{~km} \mathrm{~h}^{-1}$ (77.9 and $88.4 \%$ ) (Figure 1), probably because of the greater 
amount of energy transmitted by the vibrating rods (Torregrosa et al., 2009; He et al., 2017). In addition, at $0.6 \mathrm{~km} \mathrm{~h}^{-1}$, the intermediate clones showed a lower stripping efficiency $(77.9 \%)$ than the early $(91.5 \%)$ and late $(95.9 \%)$ ones, while at $0.8 \mathrm{~km} \mathrm{~h}^{-1}$, the stripping efficiency was similar between the early, intermediate, and late clones (93.0-96.3\%). The harvesting speed of $0.8 \mathrm{~km} \mathrm{~h}^{-1}$ favored the stripping efficiency in this research. Lower values of stripping efficiency were observed by Santinato et al. (2015c) and Silva et al. (2013) in arabica coffee cultivations, indicating the
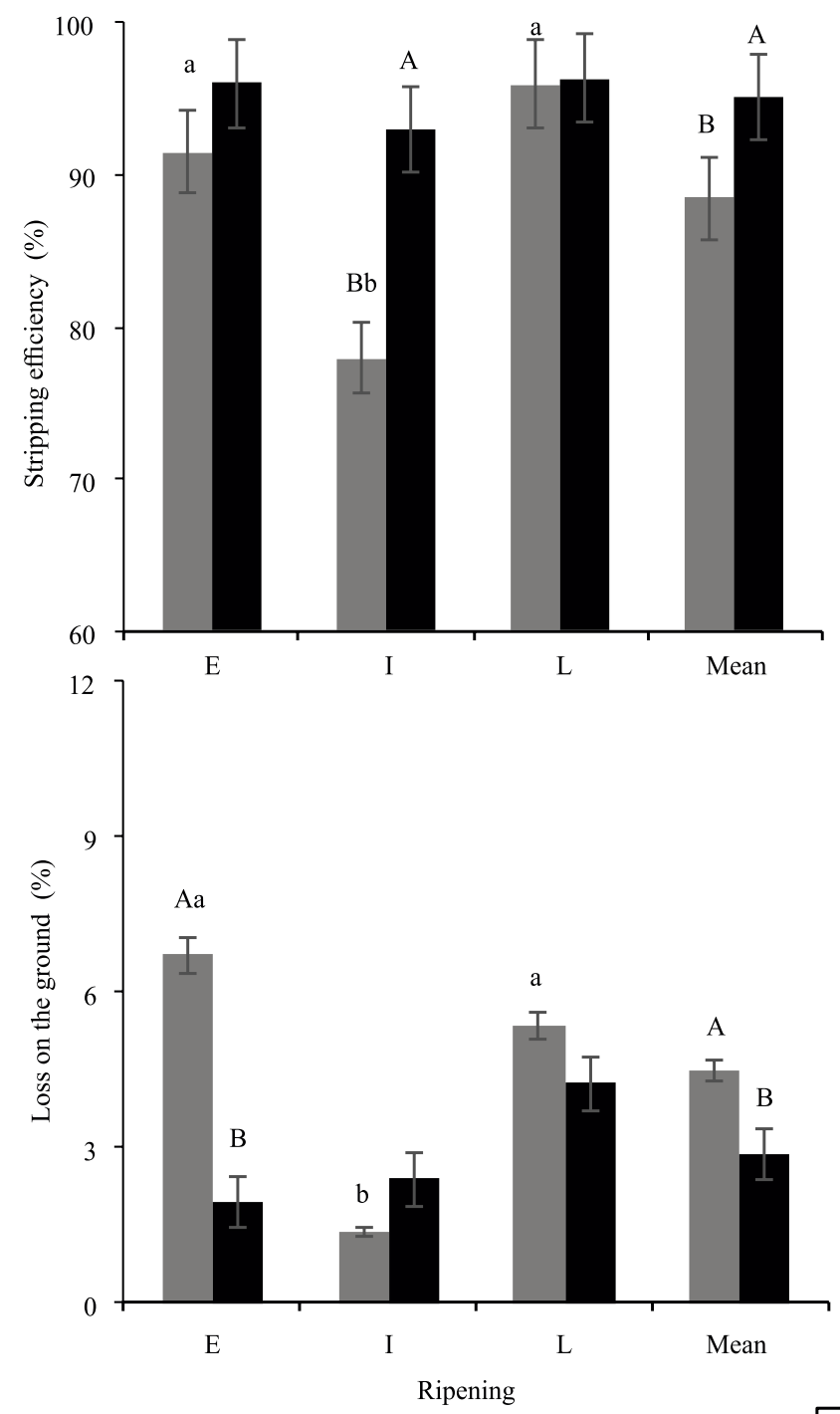

technical feasibility of the coffee harvester in 'Conilon' plantations. Greater stripping efficiency in early and late clones indicates a higher adaptability in the harvesting process.

The harvesting efficiency was higher at $0.8 \mathrm{~km} \mathrm{~h}^{-1}$ in the mean of the clones $(92.2 \%)$ than that at $0.6 \mathrm{~km}$ $\mathrm{h}^{-1}(84 \%)$, resulting from the lower amount of fruit lost to the ground, and to the greater amount of unstripped fruit, which is better described below. At the speed of $0.6 \mathrm{~km} \mathrm{~h}^{-1}$, the intermediate clones showed a lowerharvesting efficiency $(76.5 \%)$ than early $(84.8 \%)$ and
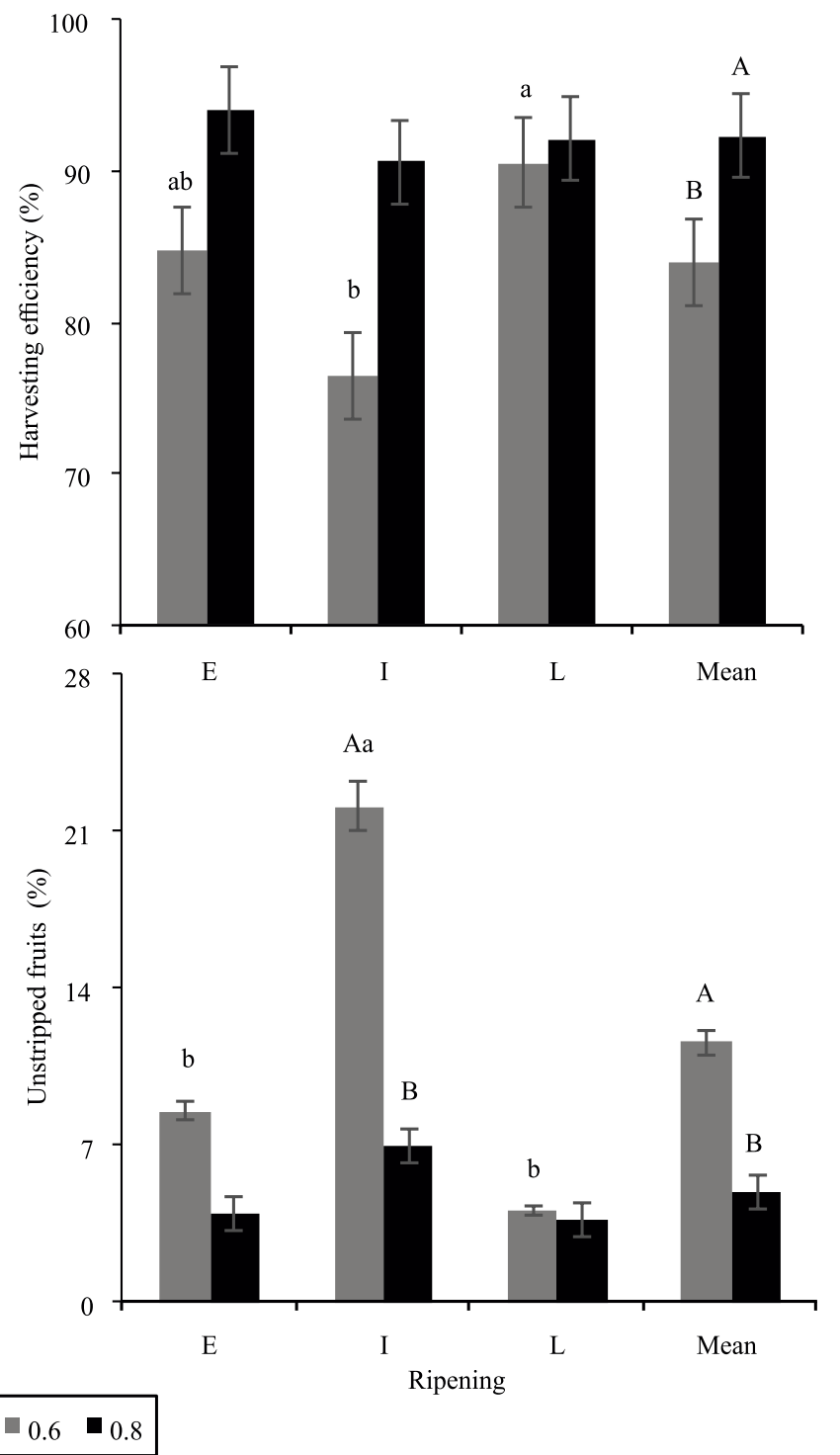

Figure 1. Stripping and harvesting efficiency, percentage of fruit loss on the ground and unstripped fruit, with a single pass of the coffee harvester with $16.67 \mathrm{~Hz}$ vibration, and speed at 0.6 and $0.8 \mathrm{~km} \mathrm{~h}^{-1}$ in Coffea canephora clones of early (E), intermediate (I), and late (L) ripening in the municipality of São Mateus, in the state of Espírito Santo, Brazil. Uppercase letters compared speed, and lowercase letters compared ripening, by Tukey's test at 5\% probability. Vertical bars represent the standard error of the mean. 
late $(90.5 \%)$ clones, while at $0.8 \mathrm{~km} \mathrm{~h}^{-1}$ the harvesting efficiency was similar between early, intermediate, and late clones (90.6-94.1\%). However, Oliveira et al. (2007a) did not observe reduction of harvesting efficiency with the increase of speed from 1.0 to 2.5 $\mathrm{km} \mathrm{h}^{-1}$. Silva et al. (2013) and Cassia et al. (2013) obtained lower-harvesting efficiency (30 to 71\%) for arabica coffee plants than that of the present study.

The percentage of fruit loss on the ground was higher at 0.60 than that at $0.80 \mathrm{~km} \mathrm{~h}^{-1}$ in the early clones $(6.7$ and $1.9 \%$ ) and in the mean of the clones ( 4.5 and $2.9 \%$ ), an it did not differ between intermediate (1.4 and 2.4\%) and late (5.4 and 4.2\%) ripening clones. The lowerharvesting speed contributes to a longer opening time of the plastic plates in contact with the trunk of the plants. These plates seal the harvester at the bottom, and a longer time with the plates open increases fruit loss on the ground (Oliveira et al., 2007a). The lowerharvesting speed results in a longer plant vibration time and greater defoliation, which hinders the transport of fruit in the conveyors and worm screw, and also increases fruit loss on the ground, which corroborates Oliveira et al. (2020). At the harvesting speed of 0.6 $\mathrm{km} \mathrm{h}^{-1}$, the intermediate clones showed a lower-fruit loss on the ground (1.4\%) than the early and late clones (6.7 and 5.4\%), while at $0.8 \mathrm{~km} \mathrm{~h}^{-1}$, the clones with early, intermediate, and late ripening did not differ (1.9 to $4.2 \%$ ). Minimizing the percentage of fruit loss on the ground increases the amount of harvested grains and profitability (Cunha et al., 2016), and minimizes phytosanitary problems (Oliveira et al., 2020).

The percentage of unstripped fruit was higher at the harvesting speed of 0.60 than at $0.80 \mathrm{~km} \mathrm{~h}^{-1}$, in the intermediate ripening clones (22.1 and 7.0\%) and in the mean of the clones (11.6 and 4.9\%). With a lower-harvest speed, a greater fruit loss was expected (Oliveira et al., 2007a); however, this depends on an interaction of the stem vibration process with the plants (He et al., 2017), that is, the increase of speed favors the transmission and distribution of vibration in the canopy of the plants, resulting in a greater amount of stripped fruit (Torregrosa et al., 2009). Unstripped fruit did not differ between harvesting speeds for early (8.5 and 4.0\%) and late (4.1 and 4.7\%) clones, which corroborates Santinato et al. (2015c). The intermediate ripening clones showed a higher percentage of unstripped fruit $(22.1 \%)$ than the early $(8.5 \%)$ and late (4.1\%) clones at $0.6 \mathrm{~km} \mathrm{~h}^{-1}$ harvesting speed, while at
$0.8 \mathrm{~km} \mathrm{~h}^{-1}$, the clones did not differ statistically (3.7 to $7.0 \%$ ). Differences for unstripped fruit between progenies of arabica coffee were observed by Silva et al. (2013), indicating the greater adaptability of some genetic materials to the mechanical harvesting process. The greater percentage of unstripped fruit increases the harvest cost (Cunha et al., 2016) and, if the farmer needs one more pass from the harvester, he can add stress to the plants (damage), reducing the crop profitability, as described by $\mathrm{He}$ et al. (2017) and Oliveira et al. (2007b). A higher percentage of unstripped fruit can also cause phytosanitary problems, as described by Oliveira et al. (2020).

The 'Conilon' coffee clones evaluated individually did not differ statistically for the variables related to the mechanized harvesting process (Figure 2). Clone 16 showed a high-plant mortality, thus, it was not evaluated. Clones 1, 4, 5, 6, 9, 10, 12, 19, 20, 21, 23, 24, and 25 showed stripping efficiency higher than $95 \%$, which would be ideal for an efficient mechanical harvesting process. Clones 4, 20, and 25 showed harvesting efficiency higher than $98 \%$, which was considered as promising result, as it was greater than those found for mechanical harvesting of arabica coffee (Santinato et al., 2015a, 2015b, 2015c; Silva et al., 2013, 2015).

Clone 6 showed the highest percentage of fruit loss on the floor (10.4\%), and clones 4 and 10 showed the lowest values for this parameter (0.96 and 0.82\%) (Figure 2). In the literature, higher values than those of this research were found, ranging from 11 to $21 \%$ (Oliveira et al., 2007b; Silva et al., 2013). High-yield crops $\left(4,260 \mathrm{~kg} \mathrm{ha}^{-1}\right.$ of benefited grains) show a tendency of more fruit fallings on the ground, which is attributed to a difficulty in this coffee harvesting system (Santinato et al., 2015a). However, this was not observed in the present works, even in clones that showed productivity of up to $13,440 \mathrm{~kg} \mathrm{ha}^{-1}$ in the experimental plots. Clones 13 and 17 had the highest percentage of unstripped fruit (23.9 and 26.5\%), while clones 20 and 21 showed 0.0 and $0.3 \%$ unstripped fruit, respectively (Figure 2). A lower percentage of unstripped fruit contributes to the reduction of phytosanitary problems with coffee borer and crop costs, without the need to harvest again (Santinato et al., 2015b; Souza et al., 2017).

On average, the clones under study showed a $15 \%$ greater defoliation in the manual harvesting $(2.7 \mathrm{Mg}$ 
$\left.\mathrm{ha}^{-1}\right)$, in comparison to mechanical one $\left(2.3 \mathrm{Mg} \mathrm{ha}^{-1}\right)$ (Figure 3). The mechanical harvesting at $0.8 \mathrm{~km} \mathrm{~h}^{-1}$ was $13 \%$ lower $\left(2.2 \mathrm{Mg} \mathrm{ha}^{-1}\right)$ than at $0.6 \mathrm{~km} \mathrm{~h}^{-1}(2.5$ $\mathrm{Mg} \mathrm{ha}^{-1}$ ). Silva et al. (2006) also observed a greater defoliation in the manual harvesting $\left(2.8 \mathrm{Mg} \mathrm{ha}^{-1}\right)$ than in the mechanical one ( 0.9 to $\left.1.5 \mathrm{Mg} \mathrm{ha}^{-1}\right)$. At the highest-harvesting speed, the lowest contact time of the stems with the coffee trees was lower, which led to less defoliation, according to Silva et al. (2006) and Oliveira et al. (2007a). A pronounced defoliation can impair the crop and increase impurities in the harvested fruit, since it reduces the photosynthetic area of the plants, and may reduce productivity of the following harvests (Coelho et al., 2015). However, 'Conilon' coffee tree is annually pruned (Verdin Filho et al., 2014), differently from arabica coffee, and a leaf area reduction occurs annually, after the harvesting, which may represent an adaptability of plants to the harvesting process, which agreed with $\mathrm{He}$ et al. (2017) and Silva et al. (2013). The clones with the highestdefoliation rates - from 0.51 to $0.56 \mathrm{~kg}$ per plant were 5, 6, 11, and 18. Similar defoliation values were observed by Oliveira et al. (2007a).
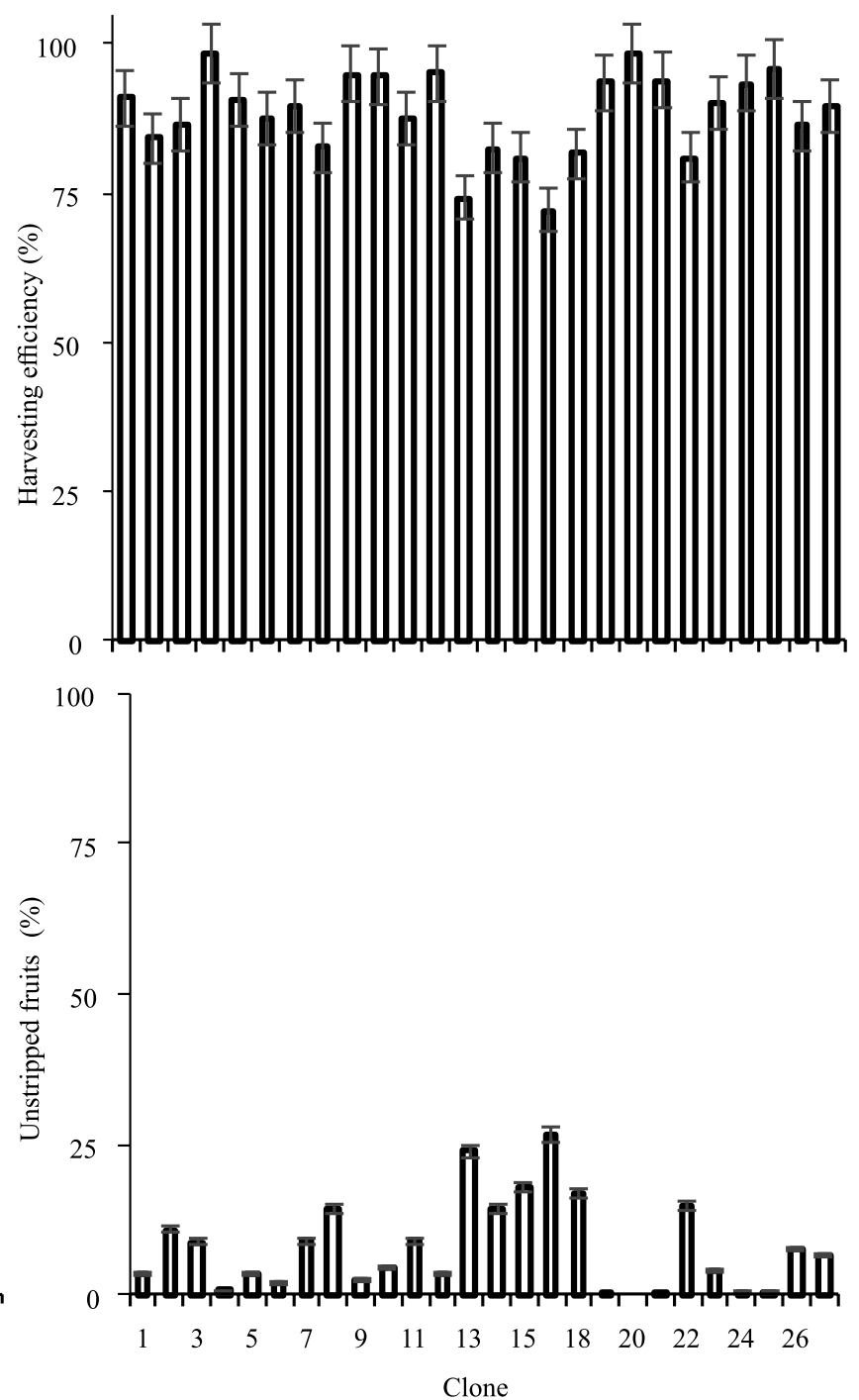

Figure 2. Early (1 to 9), intermediate (10 to 18), and late (19 to 27) ripening of Coffea canephora clones influencing the stripping and harvesting efficiencies, percentage of fruit loss on the ground, and unstripped fruit of 'Conilon' coffee, with a single pass of the harvester with $16.67 \mathrm{~Hz}$ vibration, in the municipality of São Mateus, in the state of Espírito Santo, Brazil, according to Tukey's test, at 5\% probability. Vertical bars represent the standard error of the mean. 
Stripping and harvesting efficiencies and percentage of unstripped fruit showed a linear relationship with the fruit removal force and ripening degree of 'Conilon' coffee fruit (Figure 4), which corroborates the results of
Silva et al. (2013, 2015). The increase of fruit removal force causes a decrease of stripping and harvesting efficiencies and an increase of the unstripped fruit percentage, which agrees with Torregrosa et al. (2009).
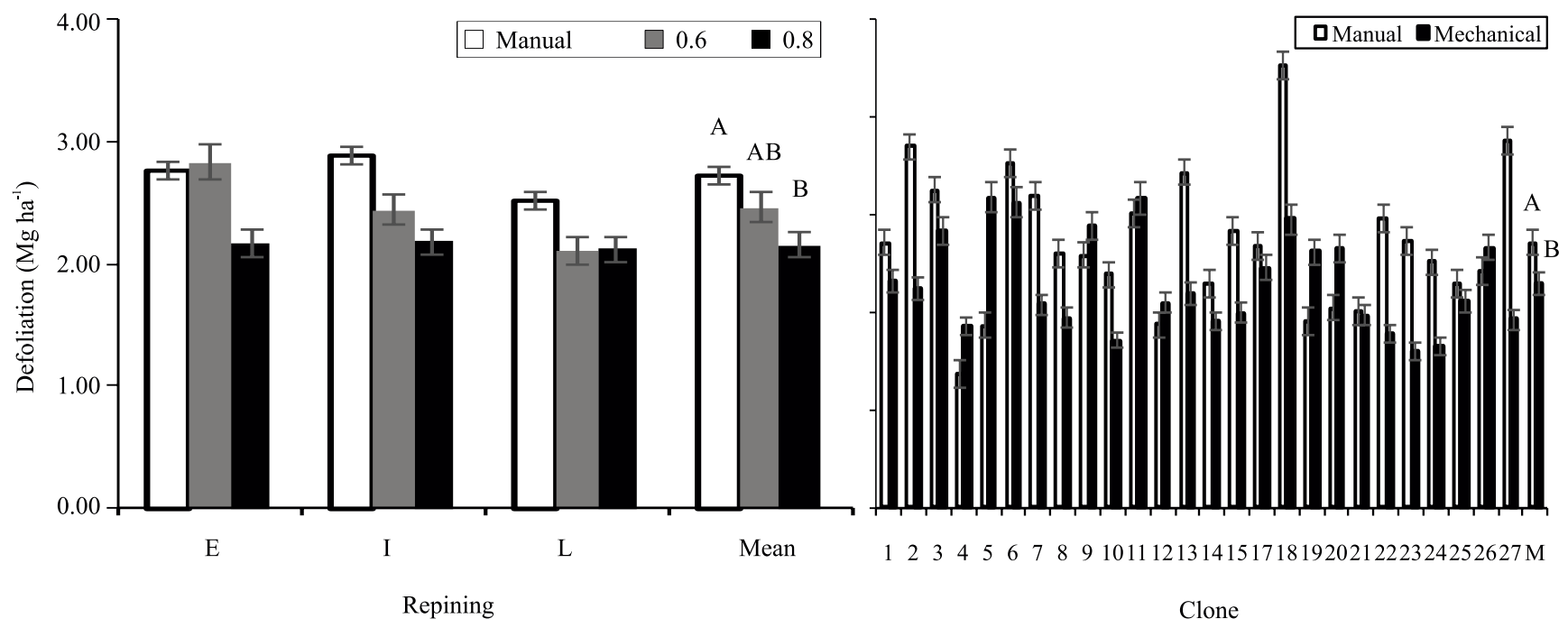

Figure 3. Defoliation of early (E, 1 to 9), intermediate (I, 10 to 18), and late (L, 19 to 27) ripening of Coffea canephora clones, after manual and mechanized harvesting, with a single pass of the harvester with $16.67 \mathrm{~Hz}$ vibration, at 0.6 and $0.8 \mathrm{~km} \mathrm{~h}^{-1}$, in the municipality of São Mateus, in the state of Espírito Santo, Brazil. Different letters represent a significant difference by Tukey's test, at $5 \%$ probability. Vertical bars represent the standard error of the mean.
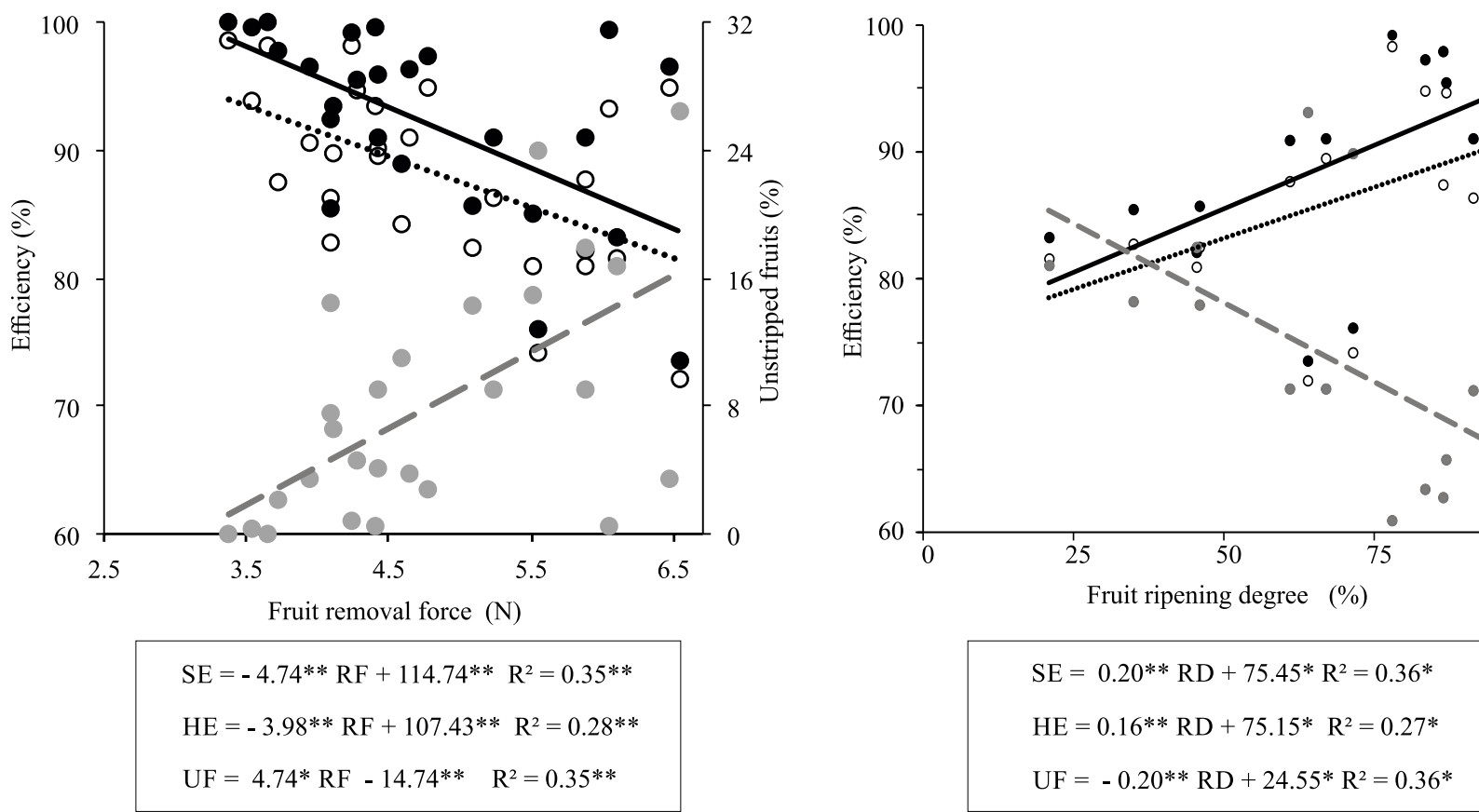

Figure 4. Stripping (SE) and harvesting efficiencies (HE), percentage of unstripped fruit (UF) related to removal force (RF), and ripening degree (RD) of Coffea canephora fruit, with a single pass of the harvester with $16.67 \mathrm{~Hz}$ vibration, in the municipality of São Mateus, in the state of Espírito Santo, Brazil. *, **Significant by the F-test, at 5\% and 1\% probability, respectively. 
Likewise, the increase of fruit ripening degree causes an increase of stripping and harvesting efficiencies and a reduction of unstripped fruit. This occurs because the fruit removal force is inversely related to the ripening degree (Silva et al., 2010, 2015).

Cherry removal force of 'Conilon' coffee ranged from 3.4 to $6.5 \mathrm{~N}$, which is similar to those values observed by Silva et al. $(2010,2013)$ for arabica coffee. In addition, the data dispersion of the linear model adjustment was observed, indicating the influence of other variables that should be studied for stripping and harvesting efficiencies and unstripped fruit, which corroborates the reports by Oliveira et al. (2007b), Silva et al. (2015), and Villibor et al. (2016).

\section{Conclusions}

1. The $88 \%$ harvesting efficiency and a lower defoliation of $15 \%$ of 'Conilon' indicates the technical viability of the use of a harvester of arabica coffee (Coffea arabica) for 'Conilon' coffee (Coffea canephora) clones, instead of manual harvesting.

2. The harvesting speed of $0.8 \mathrm{~km} \mathrm{~h}^{-1}$ results in higher-stripping and harvesting efficiencies, lower percentage of losses on the ground and unstripped fruit, regardless of the clones evaluated.

3. Fruit removal force and ripening degree of 'Conilon' coffee clones influence the stripping and harvesting efficiencies and percentage of unstripped fruit.

\section{Acknowledgments}

To Consórcio Pesquisa Café (Project number 02.13.02.044.00.00) and Fundação de Amparo à Pesquisa e Inovação do Espírito Santo (Fapes, 76420523/16), for financial support; to CNH Industry, for making the harvester available; and to Mr. Jesus Lubiana and 'Conilon' farm team for the area and test support.

\section{References}

ACOMPANHAMENTO DA SAFRA BRASILEIRA [DE] CAFÉ: safra 2019: quarto levantamento, v.5, n.4, dez. 2019.

ALVARES, C.A.; STAPE, J.L.; SENTELHAS, P.C.; GONÇALVES, J.L. de M.; SPAROVEK, G. Köppen's climate classification map for Brazil. Meteorologische Zeitschrift, v.22, p.711-728, 2013. DOI: https://doi.org/10.1127/09412948/2013/0507.

CASSIA, M.T.; SILVA, R.P. da; CHIODEROLLI, C.A.; NORONHA, R.H.F.; SANTOS, E.P. dos. Quality of mechanized coffee harvesting in circular planting system. Ciência Rural, v.43, p.28-34, 2013. DOI: https://doi.org/10.1590/S010384782012005000148 .

COELHO, A.L. de F.; SANTOS, F.L.; PINTO, F. de A. de C.; QUEIROZ, D.M de. Detachment efficiency of fruits from coffee plants subjected to mechanical vibrations. Pesquisa Agropecuária Tropical, v.45, p.406-412, 2015 . DOI: https://doi.org/10.1590/1983-40632015v4536227.

CRISOSTO, C.H.; NAGAO, M.A. Evaluation of fruit removal force of coffee cultivars. HortiScience, v.26, p.210-230, 1991. DOI: https://doi.org/10.21273/HORTSCI.26.2.210.

CUNHA, J.P.B.; SILVA, F.M. da; DIAS, R.E.B.A.; LISBOA, C.F.; MACHADO, T. de M. Viabilidade técnica e econômica de diferentes sistemas de colheita do café. Coffee Science, v.11, p.416-425, 2016.

HE, L.; FU, H.; KARKEE, M.; ZHANG, Q. Effect of fruit location on apple detachment withmechanical shaking. Biosystems Engineering, v.157, p.63-71, 2017. DOI: https://doi.org/10.1016/j. biosystemseng.2017.02.009.

LANNA, G.B.M.; REIS, R.P. Influência da mecanização da colheita na viabilidade econômico-financeira da cafeicultura no sul de Minas Gerais. Coffee Science, v.7, p.110-121, 2012.

OLIVEIRA, B.R.de; TAVARES, T.deO.; SILVA, R.P.da;BORBA, M.A. de P.; VALERIANO, T.T.B. Speed and rotation variations in gathering coffee machine. Bioscience Journal, v.36, p.61-67, 2020. DOI: https://doi.org/10.14393/BJ-v36n1a2020-42194.

OLIVEIRA, E. de; SILVA, F.M. da; SALVADOR, N.; FIGUEIREDO, C.A.P. Influência da vibração das hastes e da velocidade de deslocamento da colhedora no processo de colheita mecanizada do café. Engenharia Agrícola, v.27, p.714-721, 2007a. DOI: https://doi.org/10.1590/S0100-69162007000400014.

OLIVEIRA, E. de; SILVA, F.M. da; SOUZA, Z.M. de; FIGUEIREDO, C.A.P. de. Influência da colheita mecanizada na produção cafeeira. Ciência Rural, v.37, p.1466-1470, 2007b. DOI: https://doi.org/10.1590/S0103-84782007000500041.

PREZOTTI, L.C.; GOMES, J.A.; DADALTO, G.G.; OLIVEIRA, J.A. (Ed.). Manual de recomendação de calagem e adubação para o estado do Espírito Santo: $5^{a}$ aproximação. 5.ed. Vitória: SEEA/INCAPER/CEDAGRO, 2007. 305p.

R CORE TEAM. R: a language and environment for statistical computing. Vienna: R Foundation for Statistical Computing, 2019. Available at: <https://www.R-project.org/>. Accessed on: Apr. 62020.

RONCHI, C.P.; DAMATTA, F.M. Aspectos fisiológicos do café conilon. In: FERRÃO, R.G.; FONSECA, A.F.A. da; FERRÃO, M.A.G.; DE MUNER, L.H. (Ed.). Café conilon. 2.ed. atual. e ampl. Vitória: Incaper, 2017. Cap.5, p.103-129.

SANTINATO, F.; RUAS, R.A.A.; SILVA, R.P. da; CARVALHO FILHO, A.; SANTINATO, R. Número de operações mecanizadas 
na colheita do café. Ciência Rural, v.45, p.1809-1814, 2015a. DOI: https://doi.org/10.1590/0103-8478cr20140801.

SANTINATO, F.; RUAS, R.A.A.; SILVA, R.P. da; DUARTE, A.P.; SANTINATO, R. Análise econômica da colheita mecanizada do café utilizando repetidas operações da colhedora. Coffee Science, v.10, p.402-411, 2015b.

SANTINATO, F.; SILVA, C.D. da; SILVA, R.P. da; RUAS, R.A.A.; FERNANDES, A.L.T.; SANTINATO, R. Colheita mecanizada do café em lavouras de primeira safra. Revista Brasileira de Engenharia Agrícola e Ambiental, v.19, p.12151219, 2015c. DOI: https://doi.org/10.1590/1807-1929/agriambi. v19n12p1215-1219.

SANTOS, H.G. dos; JACOMINE, P.K.T.; ANJOS, L.H.C. dos; OLIVEIRA, V.A. de; LUMBRERAS, J.F.; COELHO, M.R.; ALMEIDA, J.A. de; CUNHA, T.J.F.; OLIVEIRA, J.B. de. Sistema brasileiro de classificação de solos. 3.ed. rev. e ampl. Brasília: Embrapa, 2013. 353p.

SILVA, F.C. da; SILVA, F.M. da; ALVES, M. de C.; FERRAZ, G.A. e S.; SALES, R.S. Efficiency of coffee mechanical and selective harvesting in different vibration during harvest time. Coffee Science, v.10, p.56-64, 2015.

SILVA, F.C. da; SILVA, F.M. da; SILVA, A.C. da; BARROS, M.M. de; PALMA, M.A.Z. Desempenho operacional da colheita mecanizada e seletiva do café em função da força de desprendimento dos frutos. Coffee Science, v.8, p.53-60, 2013.

SILVA, F.C. da; SILVA, F.M. de; ALVES, M. de C.; BARROS, M.M. de; SALES, R. de S. Comportamento da força de desprendimento dos frutos de cafeeiros ao longo do período de colheita. Ciência e Agrotecnologia, v.34, p.468-474, 2010. DOI: https://doi.org/10.1590/S1413-70542010000200028.

SILVA, F.M. da; OLIVEIRA, E.; GUIMARÃES, R.J.; FIGUEIREDO, C.A.P. de; SILVA, F.C. Desempenho operacional e econômico da derriça do café com uso da derriçadora lateral. Coffee Science, v.1, p.119-125, 2006.

SOUZA, G.S. de; LANI, J.A.; INFANTINI, M.B.; SILVA, F.M. da; ALVES, E.A.; BUENO, R. de L. Colheita mecanizada do café conilon. In: FERRÃO, R.G; FONSECA, A.F.A.; FERRÃO, M.A.G.; DE MUNER, L.H. (Ed.). Café conilon. 2.ed. atual. e ampl. Vitória: Incaper, 2017. Cap.21, p.509-530.

TORREGROSA, A.; ORTÍ, E.; MARTÍN, B.; GIL, J.; ORTIZ, C. Mechanical harvesting of oranges and mandarins in Spain. Biosystems Engineering, v.104, p.18-24, 2009. DOI: https://doi.org/10.1016/j.biosystemseng.2009.06.005.

VERDIN FILHO, A.C.; TOMAZ, M.A.; FERRÃO, R.G.; FERRÃO, M.A.G; FONSECA, A.F.A. da; RODRIGUES, W.N. Conilon coffee yield using the programmed pruning cycle and different cultivation densities. Coffee Science, v.9, p.489-494, 2014.

VILLIBOR, G.P.; SANTOS, F.L.; QUEIROZ, D.M. de; KHOURY JUNIOR, J.K.; PINTO, F. de A. de C. Determination of modal properties of the coffee fruit-stem system using high speed digital video and digital image processing. Acta Scientiarum. Technology, v.38, p.41-48, 2016. DOI: https://doi.org/10.4025/ actascitechnol.v38i1.27344. 